\section{In vitro polishing effectiveness of interdental aids on root surfaces}

\author{
Smith BA, Shanbour GS, Caffesse RG, Morrison EC and Dennison JD: In vitro \\ polishing effectiveness of interdental aids on root surfaces. J Clin Periodontol 1986; \\ 13: 597-603.
}

Abstract. The purpose of this study was: (1) to determine whether polishing standardized proximal root surfaces with dental floss, Superfloss, wood and plastic interdental cleaners, using a polishing paste, produces any significant change on root surface roughness; and (2) to determine the effectiveness of different number of strokes in polishing. 80 tooth specimens were prepared, 10 in each of 8 sample groups. Each proximal root surface was standardized with $600 \mathrm{~A}$ grit silicone carbide paper and polished with either waxed dental floss, Superfloss, wood or plastic interdental cleaners, using alkali aluminum silicate polishing paste. All specimens were mounted on a flossing machine and polished with 10 or 20 strokes. Before and after polishing, measurements were recorded with the Surfanalyzer 150 System to produce profile and average roughness tracings. Average maximum peak heights, mean number of peaks, and mean average roughness values were calculated from the tracings. The data were analyzed statistically by paired $t$-test and Student $t$-test. No significant mean differences were found between the number of strokes used. No significant differences were found for waxed dental floss in relation to the values analyzed. Significant differences were found for maximum peak heights for Superfloss following 20 strokes of polishing. However, no significant differences were found for Superfloss for mean number of peaks and average roughness. Significant differences were found for average roughness values, maximum peak heights, and mean number of peaks for the wood and plastic interdental cleaners. It was concluded that root surface roughness increased significantly with the use of wood and plastic interdental cleaners but not with waxed dental floss or Superfloss.
Billy A. Smith, Gregory S. Shanbour, Raul G. Caffesse, Edith C. Morrison and Joseph D. Dennison

Department of Periodontics, The University of Michigan School of Dentistry, Ann Arbor, Michigan, USA
Key words: In vitro study - root surface roughness - dental floss - interdental cleaners.

Accepted for publication 27 June 1985
The purpose of polishing in periodontal therapy is to remove bacterial plaque, stain and pellicle from the tooth surface and supposedly, provide the smoothest surface possible in order to facilitate plaque removal.

It has been stated that polishing will reduce the tooth surface roughness beyond that which can be achieved by root planing instruments (Doyle 1971, Walker \& Ash 1976, Zampa \& Green 1972). In this regard, polishing may be thought of as representing the final stage of root planing (Ramfjord \& Ash 1979). Unfortunately, very few investigators have studied the smoothing effect of various devices intended for polishing following root instrumentation. The studies that have looked at polishing, involved various mechanical devices and polishing pastes (Badersten et al. 1981, Doyle 1971, Hostetler 1982, Zampa \& Green 1972).
The most commonly used polishing device in dental practice today is the rotating rubber cup. However, access to interproximal tooth surfaces is limited. To compensate for this, the EVA handpiece as well as interdental cleaning aids have been advocated for use in these areas. The polishing effectiveness of these devices has only been looked at to a limited degree.

The present study was undertaken in order to determine whether polishing standardized proximal surfaces with waxed dental floss, Superfloss, wood and plastic interdental cleaners, using a polishing paste, produced any significant differences on root surface roughness, and to determine the effect of different numbers of strokes in polishing.

\section{Material and Methods}

80 freshly extracted bicuspid or molar teeth were placed in an ethyl alcoholglycerin solution (1:1 ratio) immediately following extraction. Within $24 \mathrm{~h}$ of extraction, each tooth was placed into a $30 \times 74 \times 10$ plastic block with the flattest proximal surface facing down.

To establish the standardized roughness baseline of the root surfaces, the acrylic-tooth specimens were polished on a laboratory polishing wheel with silicone carbide paper. The polishing sequence consisted of $60 \mathrm{C}$ grit, $240 \mathrm{C}$ grit, $400 \mathrm{~A}$ grit and finally $600 \mathrm{~A}$ grit silicone carbide papers*. The sequence was performed so that the direction of the abrasion produced by each successive grit was perpendicular to the one preceeding it. The final grit produced abrasion lines parallel to the long axis of the tooth.

* Mager Scientific, Inc., Dexter, Michigan 48130, USA. 
This surface (600A grit silicone paper) provided a comparable in vitro model for root surface roughness achieved by root planing (Hostetler 1982).

The area chosen for measurement was approximately $2 \mathrm{~mm}$ apical to the cementoenamel junction. This surface area was carefully examined with a light microscope at $10 \times$ power to make sure there were no artifactual fractures and that the final polishing abrasive lines were all running parallel to the long axis of the tooth. 2 notches were placed indicating the buccal and lingual extent of borders of the prepared area. These notches were then further highlighted with a fine felt-tipped pen.

The surface texture of each specimen was measured with the Surfanalyzer 150 system.

Surface texture characteristics used in this study included profile and average roughness (Walters 1983) as defined in the American Standard Bulletin ASA B46.1-1962.

The baseline surface roughness measurements were made immediately after the specimen was mounted and prepared. Each specimen was placed under the probe of the Surfanalyzer and aligned between the 2 notches. The measurements were made in a direction which gave the maximum reading, generally across the lay (American Natural Standards Surface Textures 1978). The measurements were taken at a sensitivity level of $0.05 \mu \mathrm{m} /$ division for surface profile, and $0.01 \mu \mathrm{m} /$ division for average roughness.

Following measurements of the baseline surface characteristics, the specimens were divided into 4 groups of 20 samples each. Each group was polished using a different interdental aid with an alkali aluminum silicate polishing paste*. In addition, within each group, 10 samples were polished with 10 strokes while the other 10 samples were polished with 20 strokes.

The interdental aids involved in the study were: Group I - Floss**, Group II - Superfloss***, Group III - Wood

* Pro-Care, Young Manufacturing Company, Inc., Maryland Heights, Missouri 63043, USA.

** Johnson and Johnson, Waxed Dental Floss, New Brunswick, N.J., USA

*** Educational Health Products, Inc., New Canaan, Conn. 06840, USA. interdental cleaners*, and Group IV Plastic interdental cleaners**.

The tooth specimens were mounted individually onto a flossing machine by means of an adapter plate.

The interdental cleaners were fastened to a plastic spatula by means of green or red stick compound. The spatula was secured to the lower (reciprocating) arm of the flossing machine by a locking clamp. By loosening this locking clamp, it was possible to orient the interdental cleaners in such a way that it could make maximum contact with the prepared tooth in the area to be evaluated.

The floss and superfloss under study was first threaded through a floss holder*** which was adapted to the lower reciprocating arm in the same way as the previous plastic spatula.

Prior to making contact between the interdental aid and the tooth specimen, a slurry mix of polishing paste was added to the tooth specimen in the area between the notches. Once the polishing paste was added, a $100 \mathrm{gm}$ weight was positioned on the upper balancing arm in order to make contact between the tooth and the interdental aid, and the flossing machine was activated. The waxed dental floss and the Superfloss polished the tooth surface occlusal-apically while the interdental cleaners polished in a buccal-lingual direction. Following polishing each sample was removed and cleaned with cotton under running distilled water to remove the remaining polishing paste. The tooth surface was then re-examined under the light microscope to assure that subsequent surfanalyzer measurements took place only on the portion of the tooth surface which had received the polishing treatment.

The surfaces polished with waxed dental floss and Superfloss were measured by the Surfanalyzer using the same reference marks as were used for baseline measurements. The surfaces polished with the interdental cleaners, however, had new reference marks placed. This change was made following polishing because a new lay (predominant sur-

\footnotetext{
* Johnson and Johnson, Stim-U-Dents, Gurabo, Puerto Rico 00658, USA.

** Squeak-A-Dent, Silver Manufacturing Co., Morton Grove, Ill., USA.

*** Floss Aid, J. O. Butler Company, Chicago, Ill. 60611, USA.
}

face pattern) was produced in a buccallingual direction. In accordance with the American National Standard of Surface Textures, surface roughness should be measured across the lay (American Natural Standards Surface Textures 1978) consequently, new reference points were established occlusalapically to the new lay half-way between the baseline reference marks.

\section{Quantifying root surface roughness}

Root surface roughness was evaluated by a modification of a method originally described by Creaven et al. (1980). From the profile tracing, an average of the maximum peak height $(\mu \mathrm{m})$ was calculated from 6 sections equally distributed across the tracing. The largest peak-to-valley measurement in each section was used for this calculation. To get this measurement, the number of squares were added up and multiplied by $0.05 \mu \mathrm{m}$. Since each section represented $0.1 \mu \mathrm{m}$ of the tooth surface, the total measurement of the tooth surface analyzed was $0.6 \mathrm{~mm}$. for each tooth specimen. The average number of peaks were also calculated from the same sections. All peaks were counted in each section and divided by 6 .

The average roughness $(\mu \mathrm{m})$ was calculated for each specimen from the average roughness tracing. The probe transversed the root surface 7 times before the tracing was recorded, so that the "moving average" could level off near the final average roughness value. Since this tracing resulted in a straight line, only one measurement was made by multiplying the total number of squares by $0.01 \mu \mathrm{m}$ in a vertical direction.

The data were evaluated by a paired $t$-test using MIDAS (Michigan Interactive Data Analysis System). Mean differences between groups and strokes were evaluated by Student $t$-test analysis. Differences were considered significant at $p<0.05$.

\section{Results}

The results are presented according to the type of interdental aid and number of strokes used.

Table 1 shows the paired $t$-test results from the profile and average roughness tracings of the specimens before and after polishing with waxed dental floss using 10 and 20 strokes. There was no 
Table 1. Waxed floss

\begin{tabular}{|c|c|c|c|c|c|c|}
\hline \multirow{2}{*}{$\begin{array}{l}\text { Paired t-test } \\
\text { analysis }\end{array}$} & \multirow[b]{2}{*}{$N$} & \multirow{2}{*}{$\begin{array}{l}\text { Mean } \\
\text { before }\end{array}$} & \multirow{2}{*}{$\begin{array}{c}\text { Mean } \\
\text { after }\end{array}$} & \multicolumn{3}{|c|}{ Microroughness measurements $(\mu \mathrm{m})$} \\
\hline & & & & Diff. (SD) & $t$ & Significance \\
\hline \multicolumn{7}{|c|}{ Max. peak height } \\
\hline 10 strokes & 10 & 0.292 & 0.324 & $-0.032(0.07)$ & -1.321 & 0.219 \\
\hline 20 strokes & 10 & 0.202 & 0.243 & $-0.041(0.08)^{*}$ & -1.475 & 0.174 \\
\hline \multicolumn{7}{|c|}{ Aver. roughness } \\
\hline 10 strokes & 10 & 0.084 & 0.09 & $-0.006(0.01)$ & -1.5 & 0.167 \\
\hline 20 strokes & 10 & 0.053 & 0.06 & $-0.009(0.02)^{*}$ & -1.22 & 0.827 \\
\hline \multicolumn{7}{|l|}{ No. of peaks } \\
\hline 10 strokes & 10 & 10.39 & 10.94 & $-0.55(0.8)$ & -2.158 & 0.059 \\
\hline 20 strokes & 10 & 10.27 & 10.65 & $-0.38(1.6)^{*}$ & -0.9403 & 0.371 \\
\hline
\end{tabular}

* Student $t$-test $>0.05$.

Table 2. Superfloss

\begin{tabular}{|c|c|c|c|c|c|c|}
\hline \multirow{2}{*}{$\begin{array}{l}\text { Paired } t \text {-test } \\
\text { analysis }\end{array}$} & \multirow[b]{2}{*}{$N$} & \multirow{2}{*}{$\begin{array}{r}\text { Mean } \\
\text { before }\end{array}$} & \multirow{2}{*}{$\begin{array}{c}\text { Mean } \\
\text { after }\end{array}$} & \multicolumn{3}{|c|}{ Microroughness measurements $(\mu \mathrm{m})$} \\
\hline & & & & Diff. (SD) & $t$ & Significance \\
\hline \multicolumn{7}{|c|}{ Max. peak height } \\
\hline 10 strokes & 10 & 0.261 & 0.285 & $0.024(0.05)$ & -1.4808 & 0.172 \\
\hline 20 strokes & 10 & 0.221 & 0.259 & $0.038(0.05)^{*}$ & -2.466 & 0.036 \\
\hline \multicolumn{7}{|c|}{ Aver. roughness } \\
\hline 10 strokes & 10 & 0.065 & 0.071 & $0.006(0.02)$ & -0.943 & 0.370 \\
\hline 20 strokes & 10 & 0.065 & 0.072 & $0.007(0.017)^{*}$ & -1.252 & 0.241 \\
\hline \multicolumn{7}{|l|}{ No. of peaks } \\
\hline 10 strokes & 10 & 11.12 & 11.18 & $0.06(0.52)$ & -0.361 & 0.726 \\
\hline 20 strokes & 10 & 10.99 & 10.95 & $0.04(1.0)^{*}$ & 0.1202 & 0.907 \\
\hline
\end{tabular}

* Student $t$-test $>0.05$.

Table 3. Wood interdental cleaners

\begin{tabular}{|c|c|c|c|c|c|c|}
\hline \multirow{2}{*}{$\begin{array}{l}\text { Paired } t \text {-test } \\
\text { analysis }\end{array}$} & \multirow[b]{2}{*}{$N$} & \multirow{2}{*}{$\begin{array}{l}\text { Mean } \\
\text { before }\end{array}$} & \multirow{2}{*}{$\begin{array}{c}\text { Mean } \\
\text { after }\end{array}$} & \multicolumn{3}{|c|}{ Microroughness measurements $(\mu \mathrm{m})$} \\
\hline & & & & Diff. (SD) & $t$ & Significance \\
\hline \multicolumn{7}{|c|}{ Max. peak height } \\
\hline 10 strokes & 10 & 0.344 & 0.529 & $-0.185(0.10)$ & -6.011 & 0.0002 \\
\hline 20 strokes & 10 & 0.323 & 0.626 & $-0.30(0.18)^{*}$ & -5.187 & 0.0006 \\
\hline \multicolumn{7}{|c|}{ Aver. roughness } \\
\hline 10 strokes & 10 & 0.089 & 0.179 & $-0.09(0.05)$ & -5.581 & 0.003 \\
\hline 20 strokes & 10 & 0.069 & 0.19 & $-0.12(0.05)^{*}$ & -7.211 & 0.0001 \\
\hline \multicolumn{7}{|l|}{ No. of peaks } \\
\hline 10 strokes & 10 & 13.19 & 10.24 & $+2.95(1.88)$ & 4.9407 & 0.0008 \\
\hline 20 strokes & 10 & 13.43 & 9.23 & $+4.2(1.63)^{*}$ & 8.136 & 0.000 \\
\hline
\end{tabular}

* Student $t$-test $>0.05$.

Table 4. Plastic interdental cleaners

\begin{tabular}{|c|c|c|c|c|c|c|}
\hline \multirow{2}{*}{$\begin{array}{l}\text { Paired } t \text {-test } \\
\text { analysis }\end{array}$} & \multirow[b]{2}{*}{$N$} & \multirow{2}{*}{$\begin{array}{l}\text { Mean } \\
\text { before }\end{array}$} & \multirow{2}{*}{$\begin{array}{c}\text { Mean } \\
\text { after }\end{array}$} & \multicolumn{3}{|c|}{ Microroughness measurement $(\mu \mathrm{m})$} \\
\hline & & & & Diff. (SD) & $t$ & Significance \\
\hline \multicolumn{7}{|c|}{ Max. peak height } \\
\hline 10 strokes & 10 & 0.265 & 0.547 & $-0.28 \quad(0.28)$ & -3.177 & 0.011 \\
\hline 20 strokes & 10 & 0.296 & 0.672 & $-0.376(0.20)^{*}$ & -6.003 & 0.000 \\
\hline \multicolumn{7}{|c|}{ Aver. roughness } \\
\hline 10 strokes & 10 & 0.072 & 0.25 & $-0.178(0.23)$ & -2.411 & 0.039 \\
\hline 20 strokes & 10 & 0.079 & 0.207 & $-0.128(0.05)^{*}$ & -7.877 & 0.000 \\
\hline \multicolumn{7}{|l|}{ No. of peaks } \\
\hline 10 strokes & 10 & 12.17 & 9.68 & $+2.55(1.9)$ & 4.157 & 0.002 \\
\hline 20 strokes & 10 & 12.79 & 10.28 & $+2.5(2.2)^{*}$ & 3.605 & 0.005 \\
\hline
\end{tabular}

* Student $t$-test $>0.05$. significant mean difference for the mean average of peaks using 10 or 20 strokes, using the Student $t$-test.

Table 2 shows the paired $t$-test results after polishing with Superfloss using 10 and 20 strokes. There was no significant mean difference for the mean average peak height and roughness, or number of peaks using 10 strokes. There was a significant mean difference $(p<0.05)$ for the mean average peak height but not for the mean average roughness value and the mean number of peaks using 20 strokes. The post-polishing mean value for average peak height was higher than the pre-polishing mean. No differences in results achieved with 10 and 20 strokes were found (Student $t$-test).

Table 3 shows the paired $t$-test results after polishing with wood interdental cleaners using 10 and 20 strokes. There was a significant mean difference $(p<0.05)$ in mean average peak height, mean average roughness, and mean number of peaks after polishing using 10 and 20 strokes. The post-polishing mean values for the average maximum peak height and for the average roughness were higher than the pre-polishing mean values. The post-polishing mean number of peaks was lower than the pre-polishing mean number of peaks. No differences between 10 and 20 strokes were found.

Table 4 shows the paired $t$-test results after polishing with the plastic interdental cleaners using 10 and 20 strokes. There was a significant mean difference $(p<0.05)$ for the mean average peak height, mean average roughness, and mean number of peaks using 10 and 20 strokes. The post-polishing mean values for the average maximum peak height and for the average roughness were higher than the pre-polishing mean values. The post-polishing mean number of peaks was lower than the pre-polishing mean number of peaks. No difference in results between 10 and 20 strokes were found.

Table 5 shows the paied $t$-test results before and after polishing with Superfloss and waxed dental floss using group data (combined 10 and 20 stroke samples). There was a significant mean difference $(p<0.05)$ for the mean average peak height for Superfloss but not for waxed dental floss. There was no significant mean difference for mean average roughness value and mean number of peaks for Superfloss and waxed dental floss. The post-polishing mean value for the average maximum peak height was 
Table 5. Surfanalyzer results before and after polishing with Superfloss and waxed floss; grouped data (combined 10 and 20 stroke samples)

\begin{tabular}{|c|c|c|c|c|c|c|}
\hline \multirow{2}{*}{$\begin{array}{l}\text { Paired } t \text {-test } \\
\text { analysis }\end{array}$} & \multirow[b]{2}{*}{$N$} & \multirow{2}{*}{$\begin{array}{l}\text { Mean } \\
\text { before }\end{array}$} & \multirow{2}{*}{$\begin{array}{l}\text { Mean } \\
\text { after }\end{array}$} & \multicolumn{3}{|c|}{ Microroughness measurements $(\mu \mathrm{m})$} \\
\hline & & & & Diff. (SD) & $t$ & Significance \\
\hline \multicolumn{7}{|c|}{ Max. peak height } \\
\hline Superfloss & 20 & 0.241 & 0.272 & $-0.031(0.049)$ & -2.818 & 0.0110 \\
\hline waxed floss & 20 & 0.247 & 0.283 & $-0.036(0.08)^{*}$ & -2.031 & 0.0564 \\
\hline \multicolumn{7}{|c|}{ Aver. roughness } \\
\hline Superfloss & 20 & 0.068 & 0.076 & $-0.0075(0.018)$ & -1.577 & 0.0828 \\
\hline waxed floss & 20 & 0.065 & 0.071 & $-0.0065(0.018)^{*}$ & -1.831 & 0.1313 \\
\hline \multicolumn{7}{|l|}{ No. of peaks } \\
\hline Superfloss & 20 & 11.05 & 11.06 & $-0.01(0.81)$ & -0.0551 & 0.956 \\
\hline waxed floss & 20 & 10.33 & 10.79 & $-0.46(1.04)^{*}$ & -1.993 & 0.061 \\
\hline
\end{tabular}

* Student $t$-test $>0.05$.

Table 6. Surfanalyzer results before and after polishing with wood and plastic interdental cleaners; groouped data (combined 10 and 20 stroke samples)

\begin{tabular}{|c|c|c|c|c|c|c|}
\hline \multirow{2}{*}{$\begin{array}{l}\text { Paired } t \text {-test } \\
\text { analysis }\end{array}$} & \multirow[b]{2}{*}{$N$} & \multirow{2}{*}{$\begin{array}{l}\text { Mean } \\
\text { before }\end{array}$} & \multirow{2}{*}{$\begin{array}{l}\text { Mean } \\
\text { after }\end{array}$} & \multicolumn{3}{|c|}{ Microroughness measurements $(\mu \mathrm{m})$} \\
\hline & & & & Diff. (SD) & $t$ & Significance \\
\hline \multicolumn{7}{|c|}{ Max. peak height } \\
\hline wood & 20 & 0.33 & 0.577 & $-0.244(0.15)$ & -6.998 & 0.0001 \\
\hline plastic & 20 & 0.28 & 0.609 & $-0.329(0.24)^{*}$ & -6.097 & 0.0001 \\
\hline \multicolumn{7}{|c|}{ Aver. roughness } \\
\hline wood & 20 & 0.079 & 0.185 & $-0.106(0.053)$ & -8.869 & 0.0001 \\
\hline plastic & 20 & 0.075 & 0.228 & $-0.153(0.16)^{*}$ & -4.109 & 0.0006 \\
\hline \multicolumn{7}{|l|}{ No. of peaks } \\
\hline wood & 20 & 13.31 & 9.73 & $+3.57(1.8)$ & 8.719 & 0.0001 \\
\hline plastic & 20 & 12.48 & 9.95 & $+2.53(2.01)^{*}$ & 5.602 & 0.0001 \\
\hline
\end{tabular}

* Student $t$-test $>0.05$.

higher than the pre-polishing mean value for Superfloss. No differences between floss and Superfloss were found using the Student $t$-test.

Table 6 shows the paired $t$-test results before and after polishing with wood and plastic interdental cleaners using group data (combined 10 - and 20 -stroke samples). There was a significant difference $(p<0.05)$ for the mean average peak height, mean average roughness and mean number of peaks. The postpolishing mean values for the average maximum peak height and for the average roughness were higher than the prepolishing mean values. The post-polishing mean number of peaks was lower than the pre-polishing mean number of peaks. No differences between wood and plastic interdental cleaners were found.

\section{Discussion}

Prior to the $1960 \mathrm{~s}$, a major problem in evaluating root surface roughness was the lack of an instrument that could measure the degree of roughness objectively.
During the 1960s, the Profilometer, an electro-mechanical instrument which could measure the surface roughness of an object in microinches, was used to evaluate root surface roughness (Nissle 1962).

An attempt has been made to standardize the procedure for measuring the roughness of root surfaces with the Profilometer (Green 1965). Using Green's methodology, several investigators evaluated root surface roughness (Berndt 1972, Doyle 1971, Kerry 1966, Von Volkinburg et al. 1976. Zampa \& Green 1972). In some of these investigations, however, variations in the measurements occurred following prolonged tracing with the stylus. Linear markings were observed by the stylus tracing across the root surface (Berndt 1972, Creaven et al. 1980, Kerry 1966).

The effect of the tracing stylus of the Profilometer on the root surfaces has been examined (Berndt 1972). The author demonstrated that with increased tracing passes of the stylus across the root surface, a significant decrease in root surface roughness occurred. Through SEM of the root surfaces, areas of gouging or trenching were noticed along the path of the stylus. It was considered that this method of measuring root surface roughness was a destructive procedure on tooth surfaces when $2 \mathrm{~g}$ of force were used (Berndt 1972).

Hostetler (1982) introduced the Surfanalyzer 150 system for measuring surface roughness. Like the Profilometer, this system utilizes a probe with a certain applied force. The force is necessary to insure that the stylus will follow the contour of the surface being measured. Unlike the Profilometer, the probe utilized in the Surfanalyzer 150 system is a $200 \mathrm{mg}$ force when measuring the specimen. This amount of force is well within the maximum force which can be used in measuring surface roughness $(<1.5$ g) (American Natural Standards Surface Textures 1978). Since these instruments are designed for measuring harder materials than dentin, there is a tendency for the probes, regardless of the force applied, to visibly mark its path of measurement. According to the American National Standards (ANS), the markings do not necessarily mean the measurement is incorrect (American Natural Standards Surface Textures 1978). Until investigated, however, this cannot be considered absolute (American Standards Bulletin 1962).

Measurements of all the standardized root surfaces were performed across the lay. Thus, the measurements for all the baselines were made buccal-lingually since the baseline lay was occlusal-apically, which would be representative of the direction a curette would be used to plane an interproximal surface. The same direction of measurement was also utilized on tooth specimens polished with waxed dental floss and Superfloss. However, the direction of measurement for the surfaces polished with the interdental cleaners was made occlusal-apically. This was necessary since the polishing stroke was made buccal-lingually which provided a new lay. According to the ANS, all surface roughness measurements should be made across the predominent surface in order to measure the maximum value for surface roughness (American Natural Standards Surface Textures 1978). This latter standard requirement for measuring surface roughness was not considered by previous investigators (Doyle 1971, Graham 1966, Hostetler 1982, Kerry 1966, Meyer \& Lie 1977, Von Volkinburg et al. 1976). In previous reports 
utilizing the Profilometer, readings of average roughness were taken with the stylus moving parallel to the long axis of the tooth and with the stylus moving perpendicular to the long axis of the tooth. By combining these measurements, it is possible to get a lower average roughness value. This is especially true when a unidirectional lay is produced. This type of lay was produced following hand root planing but not with ultrasonics (Ewen \& Gwinnett 1977, Kerry 1966, Suppipat 1974, Walker \& Ash 1976). This could be one of the reasons why the previous studies analyzing these types of instrumentation showed that hand curettes provided a smoother surface (Green 1965, Kerry 1966, Meyer \& Lie 1977, Von Volkinburg et al. 1976).

This methodology was also used in a polishing study (Doyle 1971). However, a difference between direction of measurements was noticed. It was stated that "roughness measured across grooves left by diamond tips used in the EVA system was 20-39 microinches greater than measurements parallel to the long axis of the tooth" (Doyle 1971).

To substantiate these assumptions and support the ANS standards, a pilot study was performed. 10 samples were prepared. After polishing with wood interdental cleaners, these samples were measured parallel to the polished surface and perpendicular to the polished surface. It was found that when measurements were taken parallel to the

Table 7. Surfanalyzer results before and after polishing with wood interdental cleaners comparing parallel and perpendicular measurements; 10 strokes

\begin{tabular}{|c|c|c|c|c|c|c|}
\hline \multirow{2}{*}{$\begin{array}{l}\text { Paired } t \text {-test } \\
\text { analysis }\end{array}$} & \multirow[b]{2}{*}{$N$} & \multirow{2}{*}{$\begin{array}{c}\text { Mean } \\
\text { before }\end{array}$} & \multirow{2}{*}{$\begin{array}{c}\text { Mean } \\
\text { after }\end{array}$} & \multicolumn{3}{|c|}{ Microroughness measurements ( $\mu \mathrm{m})$} \\
\hline & & & & Diff. (SD) & $t$ & Significance \\
\hline $\begin{array}{l}\text { Max. peak height } \\
\text { parallel } \\
\text { perpendicular }\end{array}$ & $\begin{array}{l}10 \\
10\end{array}$ & $\begin{array}{l}0.344 \\
0.344\end{array}$ & $\begin{array}{l}0.343 \\
0.529\end{array}$ & $\begin{array}{l}+0.001(0.11) \\
-0.185(0.10)\end{array}$ & $\begin{aligned} & 0.0283 \\
- & 6.011\end{aligned}$ & $\begin{array}{l}0.978 \\
0.0002\end{array}$ \\
\hline $\begin{array}{l}\text { Aver. roughness } \\
\text { parallel } \\
\text { perpendicular }\end{array}$ & $\begin{array}{l}10 \\
10\end{array}$ & $\begin{array}{l}0.089 \\
0.089\end{array}$ & $\begin{array}{l}0.129 \\
0.179\end{array}$ & $\begin{array}{l}-0.04(0.046) \\
-0.09(0.05)\end{array}$ & $\begin{array}{l}-2.738 \\
-5.581\end{array}$ & $\begin{array}{l}0.022 \\
0.003\end{array}$ \\
\hline $\begin{array}{l}\text { No. of peaks } \\
\text { parallel } \\
\text { perpendicular }\end{array}$ & $\begin{array}{l}10 \\
10\end{array}$ & $\begin{array}{l}13.19 \\
13.19 \\
\end{array}$ & $\begin{array}{l}11.83 \\
10.24 \\
\end{array}$ & $\begin{array}{l}+1.36(1.99) \\
+2.95(1.88)\end{array}$ & $\begin{array}{l}2.159 \\
4.9407 \\
\end{array}$ & $\begin{array}{l}0.059 \\
0.0008\end{array}$ \\
\hline
\end{tabular}

Table 8. Changes after polishing procedures

\begin{tabular}{ccc}
$\begin{array}{c}\text { Characteristics } \\
\text { of a smoother Surface }\end{array}$ & $\begin{array}{c}\text { Characteristics } \\
\text { of a rougher surface }\end{array}$ \\
\hline$\downarrow$ & maximum peak height & $\uparrow$ \\
$\downarrow$ & average roughness & $\uparrow$ \\
$\uparrow$ & no. of peaks & $\downarrow$ \\
\hline
\end{tabular}

polished surface, inconsistent roughness values were seen. The maximum peak height and number of peaks were statistically non-significant while average roughness gave a significantly rougher value. On the other hand, measurements made perpendicular to the polished surface showed a consistantly rougher surface, which was statistically significant (Table 7).

To evaluate the overall average roughness and the surface characteristics of the samples, average roughness and profile tracings were used. From the profile tracings, surface characteristics such as maximum peak height and number of peaks were quantified from 6 sections of each tracing representing 0.6 $\mathrm{mm}$ of the total surface measured by the Surfanalyzer. Following polishing procedures, certain changes occur. If the surface becomes smoother, there is a decrease in maximum peak height and average roughness but the number of peaks increase. However, if surfaces become rougher, the opposite occurs. Maximum peak height and average roughness increase but the number of peaks decreases (Table 8).

The paired $t$-test results for the interdental cleaners using 10 and 20 strokes showed an increase in average maximum peak height while the number of peaks decreased following polishing. From these parameters, the polishing procedure affected the surface characteristics in 2 ways. First, the polishing resulted in gross surface irregularities

which showed a large peak-to-valley height, and wide spacing between the peaks. The increase in average maximum peak height was a result of increased depth of the scratches rather than peak height. This was verified as a result of a decrease in the number of peaks following polishing.

The paired $t$-test results of the waxed dental floss showed that the surface characteristics were unchanged following polishing, regardless of the number of strokes used.

The paired $t$-test results of the Superfloss showed that the surface characteristics were unchanged following 10 strokes of polishing. However, when 20 strokes were used, the maximum peak height increased while the number of peaks did not change significantly from the baseline values. This variation in the results of the maximum peak height demonstrated a trend towards an increase in surface roughness as the strokes of polishing increase.

In comparing waxed dental floss and Superfloss, there was no significant difference between the 2 interdental aids in relation to surface characteristics or overall average roughness. This also held true for wood and plastic interdental cleaners when the 2 interdental aids were compared with each other.

The results of this study showed that polishing created a rougher surface regardless of polishing paste or mechanical technique used in polishing.

In a recent study using a Prophy Jet for polishing, the authors concluded that the Prophy Jet utilizing an abrasive powder provided a smooth surface (Atkinson et al. 1984). The average depth of penetration of the polished surface was $636.6 \mu$ with a range of $470 \mu \mathrm{m}$ to $856 \mu \mathrm{m}$ (Atkinson et al. 1984). When these results are compared with interdental cleaners, $636.6 \mu$ is considered a rough surface. In this study, the depth of penetration (maximum peak height) after polishing ranged from $0.577 \mu \mathrm{m}$ to $0.609 \mu \mathrm{m}$ which was considered a significantly rougher surface. However, the clinical significance of increased maximum peak height $(0.28$ to 0.609 $\mu \mathrm{m})$, decrease in number of peaks (13.31 to 9.73$)$ and increase in average roughness $(0.075$ to 0.228$)$ of interdental cleaners is not known at the present time.

Since the rationale for polishing includes decreasing surface roughness, the use of interdental aids should not be recommended for this purpose. How- 
ever, if polishing is needed for cleaning the root surfaces, waxed dental floss or Superfloss should be advocated during polishing, since these devices do not seem to cause an increase in surface roughness. Nonetheless, it should be stressed that the clinical significance, i.e., the effect on plaque retention and gingival response of the increase noticed in surface roughness is not known at present and certainly deserves consideration in future studies.

\section{Conclusions}

Within the limits of this investigation the following conclusions were made.

1. Root surface roughness does not increase significantly with the use of waxed dental floss and Superfloss. However, there is a trend for root surface roughness to increase with the use of Superfloss as the number of polishing strokes increase.

2. Root surface roughness increases significantly with the use of wood or plastic interdental cleaners, regardless of the number of strokes used.

3. Polishing with interdental aids after root planing does not provide a smoother root surface. The surface is either unaltered or becomes rougher depending on the device used.

\section{Zusammenfassung}

Die Effektivität von Hilfsmitteln bei der interdentalen Sauberhaltung von Wurzeloberflächen in vitro

Mit dieser Studie wurde beabsichtigt festzustellen, ob: (1) das Putzen standardisierter approximaler Wurzeloberflächen mit Zahnseide, Superfloss und mit interdentalen Säuberungshilfsmitteln aus Holz oder Kunststoff bei Anwendung einer Putzpaste imstande ist, die Oberflächenrauhigkeit von Wurzeloberflächen signifikant zu verändern; und (2) die Effektivität von Putzbewegungen bei unterschiedlicher Frequenz festzustellen. 82 Zahnprobekörper wurden hergestellt und in 8 Testgruppen eingeordnet. Jede approximale Wurzeloberfläche wurde mit Silikonkarbonpapier von $600 \mathrm{~A}$-Grit standardisiert und entweder mit gewachster Zahnseide, Superfloss oder interdentalen Holz- oder Kunststoffreinigungsgeräten bei Anwendung einer alkalischen Aluminiumsilikat Putzpaste poliert. Alle Probekörper wurden in eine Putzmaschine eingespannt und mit 10 oder 20 standardisierten Putzbewegungen poliert. Vor und nach dem Polieren wurden Messungen mit einem Surfanalysegerät vom 150-System registriert um Aufzeichnungen des Profils und der mittleren Rauhigkeit herzustellen. Durch diese Aufzeichnungen wurden die maximalem Höhen, die mittlere Anzahl höchster Punkte und die allgemein vorkommenden mittleren Rauhtiefenwerte errechnet. Die Daten wurden mit dem paarigen $t$-Test und dem Student $t$-Test statistisch analysiert. Zwischen der Anzahl der Putzbewegungen wurden keine signifikanten mittleren Unterschiede der Putzeffektivität festgestellt. Beim Anwenden gewachster Zahnseide wurden keine signifikanten Unterschiede gegenüber den analysierten Werten festgestellt. Hinsichtlich maximaler Erhebungen der Unebenheiten wurden bei Superfloss nach 20 Putzstrichen signifikante Unterchiede gefunden. Bei den Superflossversuchen wurden jedoch keine statistisch abgesicherten Unterschiede hinsichtlich der mittleren Anzahl der Höhenunterschiede und der durchschnittlichen Rauhigkeitswerte gefunden. Signifikante Unterschiede wurden jedoch bei hölzernen und Kunststoffreinigungshilfsmitteln hinsichtlich der mittleren Rauhtiefenwerte, der maximalen Höhenwerte und der mittleren Anzahl von Unebenheiten festgestellt. Es wurde gefolgert, dass die Rauhigkeit der Wurzeloberflächen bei der Anwendung interdentaler Holz- oder Kunststoffsäuberungshilfsmitteln signifikant anstieg, nicht jedoch bei der Anwendung von Zahnseide oder Superfloss.

\section{Résumé}

Efficacité du polissage in vitro d'instruments interdentaires sur les surfaces radiculaires Le but de l'étude présente était de déterminer: (1) si le polissage de surfaces radiculaires proximales standardisées avec une pâte à polir et du fil dentaire, du Superfloss, ou des curedents en bois ou en plastique produisait quelque changement sur la rugosité de la surface radiculaire; (2) l'efficacité d'un nombre variable de passages en polissant. 80 spécimens dentaires ont été préparés, 10 dans chaque groupe d'échantillons. Chaque surface radiculaire proximale était standardisée par un papier de sable en carbide de silicone 600A et polie avec du fil dentaire avec cire, du Superfloss, ou des cure-dents en bois ou en plastique avec une pâte à polir de silicate d'alumine alcalin. Tous les échantillons ont été montés sur une machine à racler et polis avec 10 ou 20 passages. Avant et après le polissage des mesures ont été prises avec le système de Surfanalyser 150 pour produire le profile et la moyenne des traces de rugosité. Les hauteurs moyennes des pics maximaux, la moyenne du nombre de pics et celle des valeurs de rugosité ont été calculées à partir des traces. Les données ont été analysées statistiquement en utilisant le test- $t$ pour données couplées et le test- $t$ de Student. Aucune différence moyenne significative n'a été trou-

\section{References}

American Natural Standards Surface Textures (1978) B466.1.

Atkinson, D. R., Cobb, C. M. \& Killoy, W. J. (1984) The effect of an air-powder abrasive system on in vitro root surfaces. Journal of Periodontology 55, 13-18.

Badersten, A., Nilveus, R. \& Egelberg, J. (1981) Effect of nonsurgical periodontal therapy. I. Moderately advanced periodontitis. Journal of Clinical Periodontology 8, 57-72.

Berndt, C. L. (1972) An evaluation of the Profilometer using scanning electron microscopy. Thesis \#706, Ann Arbor, The University of Michigan.

Creaven, P. J., Dennison, J. B. \& Charbeneau, G. T. (1980) Surface roughness of two dental amalgams after various polishing techniques. Journal of Prosthetic Dentistry 43, 289-297.

Doyle, P. T. (1971) The polishing effect of the EVA system and dental tape. Thesis \#665, Ann Arbor, The University of Michigan.

Ewen, S. J. \& Gwinnett, A. J. (1977) A scanning electron microscopic study of teeth following periodontal instrumentation. Journal of Periodontology 48, 92-97.

Graham, C. J. (1966) Home care effectiveness upon planed teeth and scaled teeth following surgery. Journal of Periodontology 37, 43-47.

Green, E. (1965) Subgingival root planing. Measurement of the effectiveness of various periodontal instruments on root surface roughness. Thesis \#476, Ann Arbor, The University of Michigan.

Hostetler, R. W. (1982) The polishing effectiveness of the EVA prophylaxis system. A in vitro study. Thesis \#1076, Ann Arbor, The University of Michigan.

Kerry, G. J. (1966) Roughness of root surfaces after use of ultrasonic instruments and hand curettes. Thesis \#508, Ann Arbor, The University of Michigan.

Meyer, K. \& Lie, T. (1977) Root surface roughness in response to periodontal instrumentation studied by combined use of microroughness measurements and scanning electron microscopy. Journal of Clinical Periodontology 4, 77-91.

Nissle, R. (1962) Ultrasonic scaling. Effect upon gingiva and the root surface. Thesis \#413, Ann Arbor, The University of Michigan.

Ramfjord, S. P. \& Ash, M. M., Jr. (1979) Periodontology and Periodontics. Philadelphia, W. B. Saunders Company.

Suppipat, N. (1974) Ultrasonics in periodontics. Journal of Clinical Periodontology 1, 206-212. Von Volkinburg, J. W., Greene, E. \& Armitage, G. C. (1976) The nature of root surfaces after curette, cavitron and alpha sonic instrumentation. Journal of Periodontology 11, 374-381. 
vée entre le nombre de passages utilisés. Aucune différence significative n'a été trouvée pour le fil de soie avec cire en rapport avec les valeurs analysées. Des différences significatives ont été obtenues pour les hauteurs des pics maximaux pour le Superfloss après 20 passages de polissage. Cependant, aucune différence significative n'a été trouvée pour le Superfloss pour le nombre moyen de pic et la rugosité moyenne. Des différences significatives ont été obtenues pour les valeurs moyennes de rugosité, les hauteurs des pics maximaux et pour le nombre moyen de pic pour les cure-dents en bois et en plastique. La rugosité de la surface radiculaire augmenterait significativement avec l'utilisation des cure-dents en bois et en plastique mais pas avec le fil dentaire avec cire ou le Superfloss.
Walker, S. L. \& Ash, M. M., Jr. (1976) A study of root planing by scanning electron microscopy. American Dental Hygiene Association Journal 50, 109-114.

Walters, C. J. (1983) Root surface roughness following the use of different polishing pastes. An in vitro study. Thesis \#1119, Ann Arbor, the University of Michigan.

Zampa, S. T. \& Greene, E. (1972) Effect of polishing agents on root roughness. Journal of Periodontology 43, 125-126.

\section{Address:}

\section{B. A. Smith}

Department of Periodontics

The University of Michigan School of Dentistry

Ann Arbor

Michigan

USA 
This document is a scanned copy of a printed document. No warranty is given about the accuracy of the copy. Users should refer to the original published version of the material. 